\title{
The criminal justice voluntary sector: concepts and an agenda for an
}

\section{emerging field}

\begin{abstract}
Authors:
Dr Philippa Tomczak, Office A19, School of Sociology and Social Policy, University of Nottingham, NG7 2RD. Email: philippa.tomczak@nottingham.ac.uk
\end{abstract}

Dr Gillian Buck, University of Chester, Warrington Campus, Crab Lane, Warrington, WA2 0DB.

Word count $\underline{8,704}$

\author{
Funding:
}

Philippa Tomczak is supported by a Nottingham Research Fellowship (2018-2021).

This research was undertaken as part of her Leverhulme Trust Early Career Fellowship (2015-2018). The authors collaborated as a result of Philippa Tomczak's British Academy Rising Star Engagement Award (2017-2018). 


\begin{abstract}
Volunteers and voluntary organisations play significant roles pervading criminal justice. They are key actors, with unrecognised potential to shore up criminal justice and/or collaboratively reshape social justice. Unlike public and for-profit agents, criminal justice volunteers and voluntary organisations (CJVVOs) have been neglected by scholars. We call for analyses of diverse CJVVOs, in national and comparative contexts. We provide three categories to highlight distinctive organising auspices, which hold across criminal justice: statutory volunteers, quasistatutory volunteers and voluntary organisations. The unknown implications of these different forms of non-state, non-profit justice involvement deserve far greater attention from academics, policymakers and practitioners.
\end{abstract}

\title{
Keywords
}

Criminal justice, Volunteers, Voluntary sector, Policing, Court, Punishment

\section{Introduction}

Criminal justice volunteering "is a way of making a difference to [...] some of the most marginalised people in this country, as well as making communities safer [...] Thousands of volunteers play a crucial role every day in helping to turn lives around, whether by mentoring young offenders, supporting victims and witnesses at court, or sitting as magistrates".

(Prison Reform Trust, 2013: 5, emphases added).

\footnotetext{
"The voluntary sector working in criminal justice [has] a workforce larger than that of the prison and probation services combined" (Mullen, 2018)
} 
Volunteers $^{\mathrm{i}}$ and voluntary organisations ${ }^{\mathrm{ii}}$ have long been involved in criminal justice (Gill and Mawby, 1990) but governments around the world are restructuring statedominated criminal justice, towards models where responsibility and funding are shared by state, private and voluntary organisations (Ransley and Mazerolle, 2017). Volunteers and voluntary organisations (with varying proportions of volunteer and paid staff) have been heavily implicated in criminal justice restructuring in e.g. England and Wales, the USA, Canada, Australia, New Zealand, France and the Nordic countries (Tomczak, 2017). Restructuring has created complex, ill-understood governance formations and partnership working iii (Kaufman, 2015; Goddard and Myers, 2018), overlaid upon longstanding, similarly ill-understood CJVVO activity. For-profit justice involvement has attracted wide-ranging interest e.g., in: policing (White, 2015); court interpreters (Aliverti and Seoighe, 2017); court escort (Whitehead, 2015); prison (Burkhardt, 2018); community supervision (Deering and Feilzer, 2015); electronic monitoring (Hucklesby, 2018). Yet, CJVVOs have not received attention commensurate with their importance anywhere in the world.

We map the scale and scope of CJVVO activity, illustrating that their scholarly neglect is problematic. Because diverse state/ voluntary sector partnerships have "largely escaped close scrutiny and serious public and policy attention" (Salamon 2015: $2149^{\text {iv }}$ ), an array of justice work and its effects are not understood and potential to shape criminal and social justice is unrecognised. Self-perpetuating reasons for this neglect include varying nomenclature ${ }^{v}$ (within and across jurisdictions); tendencies to define these actors by what they are not, rather than what they are 
(Robinson, 2016); and the sheer size and variety of their formations and roles. 'Lay' criminal justice involvement (e.g. Crawford, 2004 regarding restorative justice) includes an unpacked array of diverse formations and (non-)mandatory roles. The varying organising auspices of non-state, non-profit criminal justice involvement, and their (in)significance, have not yet been explored.

We identify three categories which hold across criminal justice: i) statutory volunteers, directly recruited and organised by state agencies; ii) quasi-statutory volunteers, organised at arm's length from statutory agencies and iii) voluntary organisations, not directly organised by the state but sometimes receiving state funding. These different forms of non-state, non-profit justice involvement and their (in)significance deserve greater attention from academics, policymakers and practitioners. By mapping these forms, this article offers a springboard for essential future scholarship. It is misleading for the Prison Reform Trust to state that every CJVVO is unproblematically turning lives around and making communities safer and evolving debates consider CJVVO's multifaceted effects (Tomczak and Thompson, 2017; Tomczak and Buck, 2019). Yet, given the sheer scale of CJVVOs, they (could) represent key criminal justice actors with unrecognised potential to shore up social exclusion and/or reshape democracy and social justice.

CJVVOs raise important questions (e.g. Zedner, 2004; Donoghue, 2014; Tomczak and Thompson, 2017). What should the state provide? Do CJVVOs represent a shift away from state power, a change in its nature and/or a change in its shape? Are CJVVOs enhancing oversight and accountability, bridging the 
democratic deficit and gap between communities and criminal justice? Are CJVVOs agents of alienation, marginalisation and/or inclusion? CJVVOs can do more than extend control, but they can also legitimise and extend coercive criminal justice institutions. We locate specific types of CJVVO involvement within a broader literature. This highlights the phenomenon as a whole, rather than reproducing piecemeal approaches that prioritise and conceal certain forms (Haddad, 2018). Currently, policing volunteers are considered a task for policing scholars (e.g. Bullock and Millie, 2018), but this obscures relevant literature from e.g. the penal voluntary sector and limits implications for theory, practice and praxis (Liebling, 2000). By utilising our cross-cutting categories, scholars need not reinvent the wheel when analysing each form of volunteer and voluntary organisation in each criminal justice institution, and new case studies can in turn enhance a broader literature.

\section{Criminal justice volunteers and voluntary organisations}

Sitting between the state, market and civil society, CJVVOs work throughout criminal justice: in police, court, prison and community service delivery, oversight and campaigning, with a social benefit mandate (Tomczak, 2017). CJVVOs work with criminalised individuals; victims; witnesses; justice practitioners; and their families. In England and Wales, "the government is committed to supporting (the) 'end-to-end' role of civil society in the criminal justice system" (p48) vi; approximately half a million volunteers work with the police (Millie, 2018); all criminal cases enter 
through magistrates courts, heavily dependent on volunteer judges (Welsh, 2016); volunteers monitor police, court and prison detention to prevent torture (Roffee, 2017); and the voluntary sector implements "exciting, groundbreaking, and yet often unrecognised work" in prisons (Abrams et al, 2016: 5).

This is not a jurisdictional quirk. In Australia, police volunteer involvement is expanding and voluntary organisations work in court, prison, substance treatment and youth support (Ransley and Mazerolle, 2017). US federal prisons depend on thousands of volunteers due to insufficient resources (Kort-Butler and Malone, 2015). The voluntary sector is the USA's primary prisoner re-entry provider (Kaufman, 2015) and manages far more persons under correctional control than forprofits (Armstrong, 2002). Even the strong Nordic welfare states involve volunteers and voluntary organisations in social service delivery (Franséhn, 2016; Helminen, 2016). Recent research exploring international criminal and human rights courts highlights the diverse participatory roles of voluntary/nongovernmental organisations, which span litigation, shaming, information sharing, helping with court administration and capacity building such that voluntary organisations "shape court resources, policies, governance and jurisprudence" (Haddad, 2018: 3). Yet, nobody has considered CJVVO significance in domestic courts.

Better understanding CJVVOs can contribute to a fuller criminology and understanding of (potential) agents of control, regulation, reform and revolution (Burrell and Morgan, 1979; Tomczak and Buck, 2019). Recognising CJVVOs' 
significance could upset the "broad professional consensus [...] and [...] widely shared sense of the goals and values that should shape criminal justice" (Garland, 2001: 27). Identifying this potential makes a small contribution to fulfilling criminologists' responsibility to advocate for social and legal justice at small and large scales (Belknap, 2015). Could cross-CJVVO reformers' collectives move from regularly complaining that "progress is altogether too slow" (Garland, 2001: 27) to reshaping social justice?

Penal voluntary organisations' vulnerability is often emphasised (e.g. Maguire, 2012) and whilst all types of CJVVO could campaign, they may perceive or experience difficulties challenging criminal justice (Helminen, 2016; Tomczak, 2017). Nevertheless, collectives of voluntary organisations can be influential. In many nations, voluntary organisations played a core role in recognising victims' rights and providing services (Williams, 2016). Victim Support Europe is a supranational network of 40 organisations, supporting over two million people affected by crime annually, in 26 European nations. It aims to be the voice of victims in Europe and has worked with EU agencies to establish EU minimum standards on the rights,

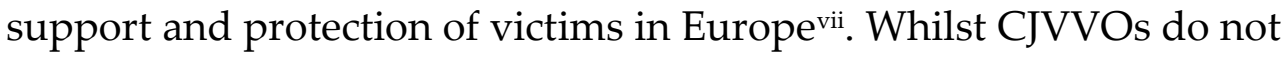
unproblematically share objectives (Ishkanian and Ali, 2018), any potential for collaboration and solidarity is impeded by lack of knowledge about similar groups.

Our conceptualisation is generated from England and Wales and draws on literature reviews and searches of the Charity Commission's website in 2018. Future comparative analyses would be valuable, being the best challenge to determinist, 
reductionist, ethnocentric analyses (Cavadino and Dignan, 2007). CJVVOs are too often considered in partisan terms: making a "special contribution" to service users (Maguire, 2012: 490), evoking "richly positive imagery" of inclusion (Armstrong, 2002: 351) and holding the state to account (Benson and Hedge, 2009: 35); or dismissed as aligned with State agendas (Kendall, 2018). Our tripartite categorisation seeks to encourage nuanced, cross-cutting analyses of different forms of voluntary action. It is relevant beyond England and Wales, given awareness that i) criminal justice, welfare and voluntary sector policies, cultures, operating assumptions and practices differ across territories and time (Tomczak, 2017); ii) criminal justice restructuring is not globally homogeneous, e.g. the Netherlands has a tradition of core statutory services being delegated to voluntary and private sector agencies, particularly in juvenile detention and probation, where some tasks are carried out by Salvation Army Probation (Wassenaar et al, 2017). Our examples have footnotes indicating relevance in other jurisdictions (unfortunately limited to Anglophone literature).

\section{Limiting lenses}

The prison's centrality in the sociology of punishment obscures the most common punishment: the fine (Young, 1992), and contributes to the 'Cinderella' status of, variously, victims (Suknaic, 1984) and community supervision (Robinson, 2016). We adopt a criminal justice lens ${ }^{\text {viii, }}$, referring to the loose amalgam of institutions that 
respond to suspected criminal law infractions. Justice agencies have divergent values and roles, but are mutually interdependent:

"without the collection of evidence no charge can be laid, without a charge there is no basis for prosecution, without evidence there can be no trial, without conviction no grounds for punishment. The beat officer and the circuit judge may inhabit different worlds and have little in common, but each has limited raison d'etre without the other" (Zedner, 2004: 20).

Burgeoning literature considers isolated aspects of CJVVOs e.g. in: policing (Bullock and Millie, 2018); prisons (Abrams et al, 2016); community sanctions (Hucklesby and Wincup, 2014); youth justice (Salole, 2016; Goddard and Myers, 2018); victim support (Svensson, 2009; Williams, 2016). Rather than presenting case studies in institutional silos (e.g. 'volunteers in probation', 'victim support' (Gill and Mawby, 1990)), we use cross-cutting categories to conceptualise CJVVOs ${ }^{\text {ix }}$. This contextualises CJVVOs (and their limited and siloed literatures) within mutually interdependent criminal justice agents, and offers sensitising concepts and broader literature that this neglected area sorely requires.

\section{Three concepts}

We identify three categories of CJVVO, which hold across criminal justice. Statutory volunteers are directly recruited, organised, supported and funded by state agencies: police, courts, prisons, probation and youth offending agencies. Statutory volunteering is unpaid, not compulsory and more organised than informal or vigilante operations. State agents, statutory volunteering and voluntary organisations can overlap. Special Constables and Magistrates are directly powerful 
volunteers, featuring throughout courts and police forces nationally (albeit not uniformly). Prison staff (particularly Chaplains), some probation agencies and Youth Offending Teams also organise volunteers to undertake work supporting their agencies. Statutory volunteers sit between 'statutory' work that must be carried out (Hill, 2010: 9) and work which supports or complements 'statutory' agency functions. They engage with clients on involuntary and voluntary bases. We do not know whether these distinctions matter, or whether statutory volunteers adopt punitive and/or rehabilitative rationales. Particularly in youth work, we do not know whether such activities are post-conviction and/or preventative.

Quasi-statutory volunteers 'independently' inspect police, court, and prison detention facilities. They include Independent Custody Visitors (police custody), Lay Observers (court custody) and Independent Monitoring Boards (prisons). Whilst they are appointed statutorily (by a Police and Crime Commissioner/Secretary of State for Justice), they are organised and supported by publicly funded arm's length bodies. Quasi-statutory volunteers form part of the UK's National Preventative Mechanism (NPM) against torture, and advocate for better services. This may appear 'niche', but given the thousands of people churning through these detention settings each day, and that people die in all of these settings, quasi-statutory volunteers' potential to further humane and just treatment (Roffee, 2017) deserves attention. This role is increasingly important within (and beyond) criminal detention globally: the 87 states party to the Optional Protocol to the United Nations Convention against Torture must establish an NPM comprising bodies that regularly examine conditions 
of detention and treatment of detainees, make recommendations, and comment on legislation ${ }^{x}$. NPMs vary across jurisdictions (Steinerte and Murray, 2009), but volunteer involvement is significant across criminal justice, immigration and mental health detention. Quasi-statutory volunteering is formalised, unpaid, not compulsory and has a degree of 'independence' from state agencies. Again, there are overlaps between state agents, quasi-statutory volunteering and voluntary organisations. We do not understand the contribution quasi-statutory volunteers (could) make to improving detention conditions.

Slightly different quasi-statutory volunteers are 'independent' volunteer lay advisors consulted in community Multi-Agency Public Protection Arrangements. Lay advisors are appointed by the Secretary of State but are 'independent', so not statutory volunteers, yet they do not have a co-ordinating body or torture prevention function. Again, we do not understand their (potential) contributions.

Voluntary organisations are formally constituted, non-profit making and 'independent', i.e. not directly organised by the state (Schwabenland, 2016: 1-2). However, voluntary organisations may receive state funds to operate and/or deliver (extra-)statutory services and they can overlap with (quasi-)statutory volunteers and state agencies. Voluntary organisations operate at local, regional, national and international level and provide services, advocacy and campaigning functions targeting 'client' groups and various decision makers (Kellow and Murphy-Gregory, 
2018). Voluntary organisations have received more attention in e.g. politics and management but are significant in criminal justice (White and Kramer, 2015).

Voluntary organisations work in varying degrees of partnership with and against statutory justice agencies, and range from corporate style registered charities with multimillion pound turnovers to grassroots style organisations. There are burgeoning literatures around voluntary organisations involved in prisons and community supervision, and victim services, but the policing and court voluntary sectors have escaped attention. Penal voluntary sector research has found that funding sources can affect but do not determine organisations' activities (Kaufman, 2015; Goddard and Myers, 2018); and that organisations range from entirely volunteer run, through combinations of paid and volunteer workers, to larger organisations usually with far fewer volunteers (Tomczak, 2017). It is not clear whether volunteers can or could be distinctive from paid voluntary organisation staff, or the similarities between (quasi-)statutory volunteers and volunteers within voluntary organisations. We do not know whether voluntary organisations follow, challenge and/or set government priorities, or the extent to which their provision differs from statutory provisions.

\title{
Statutory volunteers: organised by state agencies
}

\author{
Policing
}

“Volunteering in policing is widely recognised as an under-researched area” (Callendar et al, 2018: 3). 
In England and Wales approximately half a million volunteers work with or for the police $^{\mathrm{xi}}$ (Millie, 2018). Partly responsible is the tradition of Special Constables: volunteers with full police powers working alongside officers across all 43 police forces (Gill and Mawby, 1990; Bullock and Millie, 2018). Despite their presence and powers, Specials have been "overlooked in policing scholarship" (Bullock and Millie, 2018: 2) and, we argue, as statutory criminal justice volunteers.

Additionally, Police Support Volunteers were introduced in 1992, and now 8,000 such volunteers (who do not have police powers) contribute around 650,000 hours to policing annually (Callendar et al, 2018). They have received little research, scrutiny or debate (Bullock, 2014). London's Metropolitan Police Service has a Volunteer Police Cadet programme engaging 10-19 year olds in e.g. operational support at state occasions, seeking to improve police-youth relations and reduce vulnerability to offending and victimisation (Pepper and Silvestri, 2016). Police volunteers are likely to increase, as the Policing and Crime Act 2017 created 'Community Support Volunteers' and 'Policing Support Volunteers' whom Chief Constables may designate with powers.

State-organised volunteer police can be conceptually distinguished from informal community policing and vigilantism, and from paid 'civilian' police staff, such as Police Community Support Officers, Detention Officers, Escort Officers and Civilian Investigators in the UK (Rice, 2016). 


\section{Court}

All criminal cases start in magistrates' courts and the vast majority conclude there (Donoghue, 2014; Welsh, 2016). Magistrates are volunteers without legal qualifications, who sit as part time-judges and form the "mainstay of the system", alongside legally qualified district judges (Zedner, 2004: 17, emphases added). Yet, magistrates have been "largely neglected" by academics (and law-makers) (Bell and Dadomo, 2006: 341). Magistrates are statutory volunteers, but the Magistrates' Association is a registered charity which has influenced legislation (Grey, 2010) and educates magistrates in the law, administration of justice, treatment of the accused and crime prevention ${ }^{\text {xii. }}$

Less formally, around 1,200 Youth and Teen Court programmes involve peer volunteers as judges, jurors, attorneys and court officers in Europe, America, Australia, Asia, and Canada (Acker et al, 2001). Usually dealing with minor infractions, they are organised by police, probation, juvenile and family courts, and more broadly by schools and voluntary organisations (Peterson, 2009).

Statutory court volunteers can be conceptually distinguished from compulsory, unpaid citizen participation, e.g. mandatory jury service and mandatory lay judge service in e.g. Japan (Soldwedel, 2008), although mandatory lay participation is sometimes incorrectly classified 'volunteering' (e.g. Raine and Willson, 1995). 


\section{Prison}

Many prisons directly recruit volunteers, often through the Chaplaincy ${ }^{\text {xii }}$ (Clinks,

2016a). A governor, chaplain and medical officer are employed by the Prison Service for every prison ${ }^{\mathrm{xiv}}$, delivering faith and pastoral provisions for prisoners (Clinks, 2016b). Volunteers assist chaplains e.g. as musicians in services, and to deliver statutory duties to prisoners e.g. inductions (Clinks, 2016b). Statutory prison volunteers can overlap with other voluntary organisations and volunteers, as detailed later.

Chaplains see prison overcrowding, squalor and prisoner and staff distress daily, but their isolation from the mainstream Church of England and the 26 House of Lords Bishops limits their ability to raise ethical and practical concerns ${ }^{\mathrm{xv}}$. CJVVOs are also often isolated (Tomczak, 2017) so increasing awareness of their scale, existence and commonalities in interdependent criminal justice institutions could facilitate collaboration around shared agendas.

\section{Community supervision}

In England and Wales, community supervision is delivered by 21 Community Rehabilitation Companies (CRCs) (low- and medium-risk (ex-)offenders) and the National Probation Service (high risk (ex-)offenders) (Robinson et al, 2016). Some CRCs directly recruit volunteers. Interserve/ Purple Futures runs five CRCs for- 
profit, including Cheshire and Greater Manchester CRC, which recruits volunteers to "support" the CRC, requiring a commitment "for a minimum of one year, and $[\ldots]$ a minimum of three hours of voluntary activity each week". Volunteers may encourage probationers to:

- comply with their licence/ order terms

- complete application forms e.g. for housing

- set realistic goals and use time positively

- develop self-esteem and self-help

- access local services to overcome their problems ${ }^{\mathrm{xvi}}$.

Staffordshire and West Midlands CRC also recruits volunteers for mentoring, motivational support and education, training and employment ${ }^{\text {xvii. }}$. Commentary about the recent part privatisation of community supervision (e.g. Burke et al, 2017) has barely examined volunteer or voluntary sector involvement in this new landscape. This is peculiar given probation officers' systematic volunteer

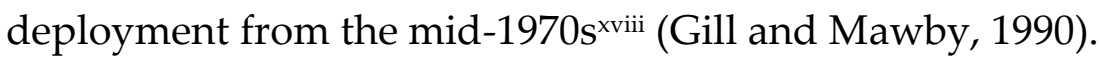

\section{Youth community sanctions}

Youth court cases (10-17 year olds) are dealt with by either three volunteer magistrates or one district judge ${ }^{x i x}$. The most frequent community sentence is referral to a panel for between three and twelve months ${ }^{\mathrm{xx}}$. Panels comprise two volunteers trained by the Youth Offending Service and a member of the Youth Offending Team (Crawford, 2004). Panels aim for the young person to make up for harms caused by 
their offending and address their offending behaviour. Although not unproblematic, by involving volunteers these panels can enable a distinctive dialogue to occur in response to crime (Crawford, 2004), and are a recognised "significant milestone in the history of restorative justice" (Rosenblatt, 2014: 291).

In addition to panels, Derbyshire Youth Offending Service recruits volunteers to work with youth at risk of offending through its Sporting Futures and Buddy Plus mentoring programmes. These encourage young people to engage with sport and discuss problems with a volunteer mentor ${ }^{\mathrm{x} i}$. Whilst there are some studies of youth mentoring (e.g. Pitts, 2001; Newburn and Shiner, 2006), such volunteering and the significance of whether activities are post-conviction or preventative have received insufficient attention.

\section{Quasi-statutory volunteers: 'independent' of state agencies}

\section{Police}

2,000 Independent Custody Visitors make unannounced visits to custody blocks to check and report on detainees' rights, entitlements and wellbeing. Visitors are funded, managed and administered by Police and Crime Commissioners and are members of the Independent Custody Visiting Association, a Home Office funded umbrella body (Kendall, 2018). Again, custody visiting is held to be "almost completely ignored by police scholars" (Kendall, 2018: 1), obfuscating e.g. prison literature. Kendall (2018) provides the first examination of Independent Custody 
Visitors, arguing that the power wielded by police undermines their independence and posts risks to detainee welfare, albeit in an overgeneralised account from one police force, that is highly critical of volunteer capabilities and neglects volunteer agency, motivations and contributions (Wooff, 2018).

\section{Court}

70 Lay Observers inspect court custody and cellular vehicles. Lay Observers have a Ministry of Justice (MoJ) secretariat and are appointed by the Secretary of State for Justice. Commentary is limited to Carver's (2016) note of their existence. Although ostensibly a niche area, there are 50,000 movements of people under escort and court custody each month ${ }^{x x i i}$ and individuals die in court custody, e.g. Sivaraj Tharmalingam died April 2015 at Thames Magistrates Court ${ }^{x x i i i}$.

\section{Prison}

Independent Monitoring Boards monitor whether prisoners are treated with fairness and humanity, and prepared properly for release ${ }^{\mathrm{xxiv}}$ (Stern, 2010). Members are expected to be impartial and apolitical, but are appointed by the Secretary of State for Justice ${ }^{\mathrm{xxv}}$. The taxpayer funds secretariat support, volunteer training and volunteers' travel expenses. Independent Monitoring Boards can be more than symbolic and further "humane and just treatment of some of the state's most

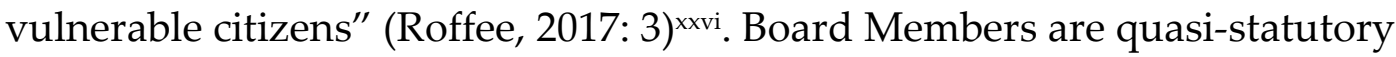


volunteers, but their charity, the Association of Members of Independent Monitoring Boards, seeks to achieve a public voice and speak out about what Boards hear and see ${ }^{x x v i i}$.

\section{Public protection}

Two volunteer lay advisors, appointed by the Secretary of Statexxviii, provide an independent perspective on each police force's Multi-Agency Public Protection Arrangements (which engage probation, police and prisons in managing sexual and violent offenders). Police, probation and prisons must consult their lay advisers in exercising their functions (MoJ, 2012). Lay advisers sit on each area's Strategic Management Board, as reviewers and observers with local knowledge (MoJ, 2012). Beyond brief mentions (e.g. Thomas, 2008), we know little about these volunteers and how they may affect decision making.

\section{Voluntary organisations: not directly organised by state agencies}

\section{Policing}

The vibrant policing voluntary sector has escaped attention. We introduce Neighbourhood Watch and Street Pastor crime prevention; Crimestoppers, which feeds anonymous information to police; and voluntary organisations supporting police and their families. 
41 UK Neighbourhood Watch schemes were registered charities in early 2018.

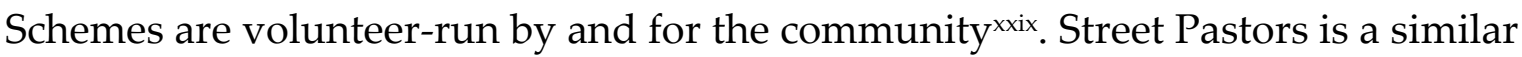
Christian initiative. Volunteers offer night-time care on city streets, e.g. first aid and helping the inebriated (Middleton and Yarwood, 2015). 133 UK Street Pastor schemes were registered charities in early 2018. For example, trained volunteers from local churches have patrolled Ashford since 2010. Their activities include: "handing out space blankets outside nightclubs and flip-flops to clubbers unable to walk home in their high-heeled footwear; giving out water and lollipops [...]; providing first aid [...]; arranging taxis for those unable to get home [...]; (removing) glass bottles and other potential weapons from the streets [...] to discourage violence and vandalism" (p. 3) ${ }^{\mathrm{xxx}}$. They state: "the Police are one of our biggest supporters, $[\ldots]$ on the nights we are on shift the crime rates drop. Just by our presence on the street and by engaging with people we [...] prevent problems" $(\mathrm{p} 4)^{\mathrm{x} x \mathrm{i}}$.

Crimestoppers in England and Wales ${ }^{\mathrm{xx} x i i}$ is a registered charity working to detect, reduce and prevent crime by passing anonymous information to police: providing 136,000 pieces of information in 2016-7. Crimestoppers have 44 regional volunteer committees, including 370 volunteers who work with police, Police and Crime Commissioners and Community Safety Partnerships to promote Crimestoppers and manage local campaigns. Without the "great amount of time" donated by volunteers, the charity "would not be able to sustain the current level of activities" (p. 16) xxxiii. 87 full time equivalent salaried staff and regional managers 
supported volunteer committees. Their £5million 2016 income was mainly from central government and donations/ legacies. Following the priorities set by the national government, in 2016-7 Crimestoppers worked to tackle modern day slavery, domestic abuse and honour-based abuse ${ }^{\mathrm{xxxiv}}$. Crimestoppers obtained funding from the High Sherriff's Police Trust and the Skelton Bounty Charitable Trust to tackle modern day slavery in partnership with Greater Manchester Police.

A range of registered charities assist the police and their families. Injured officers are supported by e.g. the Blue Lamp Foundation; Police Rehabilitation Centre and North West Police Benevolent Fund. Families of police officers who have died on duty are offered support from e.g. Care of Police Survivors.

\section{Court}

Registered charity Citizens Advice runs a Witness Service supporting prosecution and defence witnesses in over 240 criminal courts. Over 3,000 trained volunteers provide free, independent practical and emotional support for witnesses, assisting 156,400 people in 2016-7xxxv. Citizens Advice received $£ 17$ million from the MoJ and Welsh government to deliver this service ${ }^{\mathrm{xx} x \mathrm{i}}$.

Registered charity Victim Support provides practical and emotional support $^{\mathrm{xx} x \mathrm{vii}}$ for victims and witnesses from three years old to give evidence, including victims of sexual violence and domestic abuse. Support includes pre-court visits, practice using video links, meetings with judges and advocates, and self- 
esteem building activities. Victim Support assisted 1,200 witnesses through this service in $2016-7$ (p 17) $)^{x x x v i i}$.

\section{Prison and community supervision}

Existing literature explores penal voluntary organisations' work (Tomczak, 2017) e.g. with prisoners (Abrams et al, 2016), prisoners' families (Woodall and Kinsella, 2018) and in resettlement (Thompson and Thomas, 2017). Peer mentoring by (ex-)prisoners is a growing area internationally (Buck, 2018) and commentary has explored peer interventions co-ordinated by voluntary organisations: in Young Offender Institutions, prisons and community supervision (e.g. Fletcher and Batty, 2012; Jaffe, 2012; South et al, 2017). To this literature, we add understanding of how varying CJVVOs can combine, using the case study of HMP Send, England.

Prison chaplains organise statutory volunteers and may also engage with voluntary organisations. HMP Send is a women's prison in Surrey where many CJVVOs work with prisoners (Clinks, 2016b). The Nazareth Way is a voluntary organisation working under the direction of Send's Managing Chaplain, but further voluntary organisations work through the Chaplaincy, including: Official Prison Visitors; Prison Fellowship; the Mothers Union (Diocese of Guildford); Changing Tunes; and Cruse Bereavement Care. Through the Chaplaincy and beyond, prisoners "are supported by more than 50 voluntary organisations covering a diverse range of issues from family support (Salvation Army / Send Family Link / Prisoner Advice 
Service / SWS Domestic Abuse / Samaritans) to drug, alcohol, health and related issues (Alcoholics Anonymous / Surrey Harm Reduction Outreach / Cruse Bereavement Counselling / Guildford College Counsellors)" (p 4) ${ }^{\mathrm{xxxix}}$. It is perhaps notable that HMP Send is one of the few prisons to achieve the Inspectorate's highest grading for outcomes across all four healthy prison tests $(\mathrm{p} 5)^{\mathrm{xl}}$.

\section{Victims}

Victim Support in England and Wales ${ }^{x l i}$ was amongst the first victims' organisations, emerging in the 1970s (Mawby, 2016). From its inception, "victim support as an independent organisation utilising community resources and deploying volunteers was stressed" (Gill and Mawby, 1990: 77). It supports anyone affected by crime, no matter when it occurred or whether it was reported. It seeks to "help and empower people affected by crime and traumatic incidents to move beyond crime and [...] feel

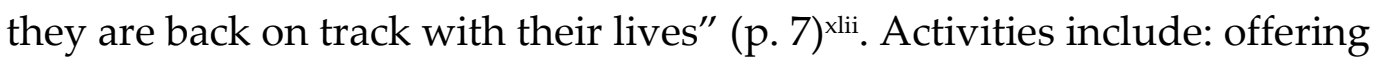
confidential emotional and practical support; providing specialist services for victims of e.g. domestic abuse; championing victims' rights and issues locally and nationally, working closely with policy-makers and commissioners (p. 8) xliii. $^{\text {. }}$ Alongside paid staff, 1,287 volunteers gave 267,144 hours of their time to support victims of crime in 2016-17, estimated to be worth $£ 3.84$ million (p. 16) ) $^{\text {xliv. Local }}$ voluntary organisations also support victims, e.g. Hull Rape Crisis offers free 
telephone and face to face support and counselling to any female over the age of 14 who has been raped or sexually abused at any time ${ }^{x l v}$.

\section{Fluidity and areas for investigation}

Our CJVVO categories facilitate further analyses, but there is fluidity between services, service users and practitioners (Buck, 2016). CJVVO activity overlaps with what can and should be provided by the state, and straddles criminal exclusion and social deprivation (Cook, 2006). As such, our concepts should be treated as sensitising devices rather than fixed, bounded categories. This section signposts five forms of fluidity, the implications of which are not yet understood.

Appropriate adults support juveniles and vulnerable adults in police custody, per the Police and Criminal Evidence Act 1984 Code of Practice (Code C). Volunteers provide appropriate adult services for Youth Offending Teams, local authorities and through voluntary organisations, but appropriate adults are not exclusively volunteers and may be e.g. guardians, paid professionals or social workers (Pierpoint, 2011). Various reviews have recommended volunteer appropriate adults to e.g. enhance availability and promote 'good citizenship', but schemes are locally operated by various bodies including Youth Offending Services ${ }^{\text {xlvi }}$ and not all areas use volunteers (Pierpoint, 2006). The National Appropriate Adult Network is a registered charity working to ensure that "every child and mentally vulnerable adult detained or interviewed by the police has their rights and welfare safeguarded 
effectively by an appropriate adult", providing, inter alia, professional development and internet resources for appropriate adults, and an online gateway linking potential volunteers to local schemes ( $\mathrm{p} 5)^{\mathrm{xlvii}}$. Appropriate adult services for juveniles are required by statute, so arguably should not be subsidised by unremunerated volunteer and voluntary organisation involvement.

Hucklesby and Wincup (2014) demonstrate widespread blurring of the roles of volunteers and paid staff in mentoring, with e.g. voluntary sector mentoring meetings being designated as bail appointments to free up overstretched statutory staff, thus becoming a breachable activity that could result in arrest. Such blurring is held to disguise enhanced control behind philanthropic agendas (Hucklesby and Wincup, 2014), although such critiques do not justify how the state and voluntary organisations (potentially) have inherently different ways of governing (Saloe, 2016).

Buck (2016: 107) illustrated the case of Phil, an ex-offender who informally volunteered to deliver peer mentoring and resettlement support for adult prisoners, having been invited back into prison post-release. His paid work is delivering a Housing Association's youth inclusion programme, seeking to "challenge young people's attitudes about crime and change negative lifestyles", straddling criminal exclusion and social inequality.

Remedi is a charity with paid and volunteer staff in the North of England, providing restorative justice and mentoring services to address conflict across 
offence types, in partnership with police, probation, youth offending, prisons and victim services $^{x l v i i i}$. Victims and offenders can self-refer to Remedi's services which are free at the point of delivery. Remedi also operate outside criminal justice with families and schools ${ }^{x l i x}$. Their Safer Schools model is delivered in three Sheffield schools serving deprived areas with significant BME populations and high exclusion/ poor attendance rates. Remedi have dedicated on-site restorative practitioners who address conflict in and around the schools ${ }^{1}$. Remedi's work illustrates fluidity between the exclusionary criminal justice system and attempts to mitigate the effects of social inequality. How is this beneficial and problematic?

Similarly, Out There is a charity offering free, confidential support for prisoners' families serving the 'sentence on the outside' in Greater Manchester ${ }^{\text {li }}$. Their four paid and eight volunteer staff run outreach sessions at HMP Manchester, support groups to counter the loneliness, isolation and stigma that prisoners' families can experience, and groups for sex offenders' families. They also provide phone calls, home visits, liaison with prison and probation, referral to services, and help from the hardship fund, with transport and attending appointments ${ }^{\text {lii. }}$ They distribute food parcels to families, help families in hardship replace domestic appliances, work with Catholic Family Care to provide essential clothing and bedding and provide hardship funding. Again, this work straddles criminal justice and social inequality. 


\section{Conclusion}

This article is significant because it illustrates the pervasive volunteer and voluntary organisation activity throughout criminal justice. Our tripartite conceptualisation demonstrates links and overlaps between different forms of CJVVO, which tend to be examined in isolation. CJVVOs have hitherto unrecognised potential to shore up criminal justice and/or reshape social justice, but we do not understand the forms and functions that facilitate these outcomes. Overlooking CJVVOs has political implications, meaning that a (potential) swathe of regulatory activity (which extends beyond criminal justice into social marginalisation) is not recognised, and limiting potential for radical action (Tomczak and Buck, 2019). We call for others to utilise our typology to advance the research agenda and activism across this significant, but previously fragmented and overlooked field.

Martin and Varney (2003: 6) argue for reflection "on how, when and under what circumstances [...] everyday resistances give rise to larger more capable challenges" against large and small instances of aggression, repression and oppression. Penal voluntary organisations make important contributions: saving (ex)offender lives (Tomczak and Thompson, 2017); promoting personal growth and change (Buck, 2018); helping reduce recidivism (Lewis et al, 2007; Sharkey et al, 2017), which, given the $£ 15$ billion annual costs and social harms of reoffending in England and Wales (MoJ, 2016: 3) deserves further exploration; and campaigning against social exclusion, even under neoliberal governance (Goddard and Myers, 
2018). Some CJVVOs are also considered to have limiting or negative consequences including shoring up dangerous police detention conditions (Kendall, 2018), obfuscating the flow of private funds into public policing operations and priorities (Lippert and Walby, 2017); and shaping victim behaviour to align with the criminal justice priority of bearing witness in court (Svensson, 2009). It is essential to locate and contextualise accounts of particular types of CJVVO activity amidst the whole sector, and conceptualise CJVVOs without essentialising them and their potential (Tomczak and Buck, 2019).

England and Wales still has the highest imprisonment rate in Western Europe, with in excess of 80,000 prisoners (Prison Reform Trust, 2017), confined within a violent, unsafe prison estate (Council of Europe, 2017). CJVVOs of all forms could challenge this situation more overtly and forcefully. Building awareness of CJVVOs is an important step towards realising their reformative and/or revolutionary potential. We hope others will take up our call for further analyses in this area.

\section{References}

Abrams, L. S., Hughes, E., Inderbitzin, M., \& Meek, R. (Eds.) (2016) The Voluntary Sector in Prisons: Encouraging Personal and Institutional Change. New York: Springer.

Acker, J., Hendrix, P. N., Hogan, L., \& Kordzek, A. (2001) ‘Building a better youth court'. Law E Policy, 23(2): 197-215. 
Aliverti, A. \& Seoighe, R. (2017) 'Lost in translation? Examining the role of court interpreters in cases involving foreign national defendants in England and Wales'. New Criminal Law Review: In International and Interdisciplinary Journal 20(1): 130-156. Allspach, A. (2010) 'Landscapes of (neo-) liberal control: The transcarceral spaces of federally sentenced women in Canada'. Gender, Place and Culture 17(6): 705-723.

Armstrong, S. (2002) 'Punishing not-for-profit: Implications of nonprofit privatization in juvenile punishment'. Punishment and Society, 4(3): 345-368.

Belknap, J. (2015) 'Activist Criminology'. Criminology, 53(1): 1-22.

Bell, B. \& Dadomo, C. (2006) 'Magistrates' Courts and the 2003 Reforms of the Criminal Justice System'. European Journal of Crime, Criminal Law and Criminal Justice 14: 339365.

Buck, G. (2016) 'Peer mentoring and the role of the voluntary sector in [re] producing 'desistance': identity, agency, values, change and power' (unpublished PhD thesis, Keele University, UK).

Buck, G. (2018) 'The core conditions of peer mentoring'. Criminology and Criminal Justice, 18(2): 190-206.

Bullock, K. (2014) Citizens, Community and Crime Control. Basingstoke: Palgrave Macmillan. Bullock, K. \& Millie, A. (Eds.) (2018) The Special Constabulary. Abingdon: Routledge. Burke, L., Millings, M., \& Robinson, G. (2017) ‘Probation migration (s): Examining occupational culture in a turbulent field'. Criminology \& Criminal Justice, 17(2): 192208. 
Burkhardt, B. (2018) ‘Contesting market rationality: Discursive struggles over prison privatization'. Punishment and Society onlinefirst.

Burrell, G. \& Morgan, G. (1979) Sociological Paradigms and Organisational Analysis. Abingdon: Routledge.

Callender, M., Pepper, M., Cahalin, K., \& Britton, I. (2018) ‘Exploring the police support volunteer experience: findings from a national survey'. Policing and Society onlinefirst.

Carver, R. (2016). United Kingdom. In Carver, R. \& Handley, L. (Eds.) Does Torture Prevention Work? Liverpool: Liverpool University Press, pp. 105-142.

Cavadino, M. \& Dignan, J. (2007) The Penal System. London: Sage.

Clinks (2016a) Valuing volunteers in prison. Available at:

https://www.clinks.org/sites/default/files/basic/files-

downloads/valuing volunteering in prison -

a review of volunteer involvement in prisons july 2016 final.pdf (accessed 16 July 2018).

Clinks (2016b) HMP Send and the Nazareth Way. Available at:

https://www.clinks.org/sites/default/files/basic/files-downloads/vvcase study $4 \mathrm{hmp}$ send nazareth way final.pdf (accessed 16 July 2018)

Cook, D. (2006) Criminal and Social Justice. London: Sage.

Council of Europe (2017) Report to the Government of the United Kingdom on the visit to the United Kingdom carried out by the European Committee for the Prevention of Torture and Inhuman or Degrading Treatment or Punishment (CPT) from 30 March to 12 April 2016. 
Crawford, A. (2004) 'Involving lay people in criminal justice'. Criminology and Public Policy, 3(4): 693-702.

Deering, J. \& Feilzer, M. (2015) Privatising Probation. Bristol: Policy Press.

Donoghue, J. C. (2014) 'Reforming the Role of Magistrates: Implications for Summary Justice in England and Wales'. The Modern Law Review 77(6): 928-963.

English, L. M. (2013) 'The impact of an independent inspectorate on penal governance, performance and accountability: Pressure points and conflict "in the pursuit of an ideal of perfection"'. Critical Perspectives on Accounting, 24(7-8): 532-549.

Fleming, J. (2005) 'Working Together': Neighbourhood Watch, Reassurance Policing and the Potential of Partnerships'. Trends and Issues in Criminal Justice 303. Available at: www.aic.gov.au/publications/tandi (accessed 16 July 2018)

Fletcher, D. R., \& Batty, E. (2012). Offender peer interventions: What do we know. Centre for Regional Economic and Social Research: Sheffield Hallam University, 1-26.

Foucault, M. (1977) Discipline and Punish. London: Allen Lane.

Franséhn, M. (2016) ‘Laypersons or professionals? Ambivalence about voluntary contact persons in social services in Sweden'. Nordic Social Work Research, 6(2): 102-113.

Garland, D. (2001) The Culture of Control. Oxford: Oxford University Press.

Gill, M. L. \& Mawby, R. I. (1990) Volunteers in the Criminal Justice System: A Comparative Study of Probation, Police, and Victim Support. Milton Keynes: Open University Press.

Goddard, T. \& Myers, R. (2018) Youth, Community and the Struggle for Social Justice. Abingdon: Routledge. 
Greenberg, M. A. (2014) American Volunteer Police: Mobilizing for Security. Boca Raton: CRC Press.

Grey, D. J. (2010) 'Women's Policy Networks and the Infanticide Act 1922'. Twentieth Century British History, 21(4): 441-463.

Haddad, H. N. (2018) The Hidden Hands of Justice: NGOs, Human Rights, and International Courts. Cambridge University Press.

Helminen, M. (2016) `Nordic and Scottish Civil Society Organisations Working with Offenders and the Effects of Service Delivery: Is Pursuing Mission Impossible Whilst Bidding for Contracts?' The Howard Journal of Crime and Justice, 55(1-2): 73-93.

Hill, A. (2010). Working in statutory contexts. Cambridge: Polity Press.

Hucklesby, A. (2018). A Complicated Business: The Operational Realities of Privatised Electronic Monitoring of Offenders. In Hucklesby, A. \& Lister, S. (Eds.) The Private Sector and Criminal Justice. London: Palgrave Macmillan, pp. 223-258.

Hucklesby, A. \& Corcoran, M. (Eds.) (2016) The Voluntary Sector and Criminal Justice. London: Palgrave Macmillan.

Hucklesby, A. \& Wincup, E. (2014) 'Assistance, Support and Monitoring? The Paradoxes of Mentoring Adults in the Criminal Justice System'. Journal of Social Policy, 43(2): 373390.

Ishkanian, A., \& Ali, I. S. (2018) 'From Consensus to Dissensus: The Politics of Antiausterity Activism in London and Its Relationship to Voluntary Organizations'. Journal of Civil Society, 14(1): 1-19. 
Jaffe, M. (2012) `Peer support and seeking help in prison : a study of the Listener scheme in four prisons in England' (unpublished PhD thesis, Keele University, UK).

Jägervi, L. \& Svensson, K. (2015) ‘Conceptions of Gender and Age in Swedish Victim Support'. International Review of Victimology, 21(2): 217-231.

Kaufman, N. (2015) ‘Prisoner incorporation: The work of the state and non-governmental organizations'. Theoretical Criminology, 19(4): 534-553.

Kaufman, N. (2018) `Nongovernmental Organizations and Postprison Life: Examining the role of Religion'. Punishment and Society, onlinefirst.

Kellow, A. \& Murphy-Gregory, H. (Eds.) (2018) Handbook of Research on NGOs. Cheltenham: Edward Elgar Publishing.

Kendall, J. (2018) Regulating Police Detention: Voices from Behind Closed Doors. Bristol: Policy Press.

Kort-Butler, L. A. \& Malone, S. E. (2015) ‘Citizen volunteers in prison: bringing the outside in, taking the inside out', Journal of Crime and Justice, 38(4): 508-521.

Lewis, S., Maguire, M., Raynor, P., Vanstone, M., \& Vennard, J. (2007) ‘What works in resettlement? Findings from seven Pathfinders for short-term prisoners in England and Wales'. Criminology \& Criminal Justice, 7(1): 33-53.

Liebling, A. (2000) ‘Prison officers, policing and the use of discretion'. Theoretical Criminology, 4(3): 333-357.

Lippert, R. K. \& Walby, K. (2017) ‘Funnelling through foundations and crime stoppers: how public police create and span inter-organisational boundaries'. Policing and Society 27(6): 602-619. 
Lippert, R. \&Wilkinson, B. (2010) Capturing crime, criminals and the public's imagination: Assembling Crime Stoppers and CCTV surveillance. Crime, Media, Culture 6(2): 131152.

Lowman, J., Menzies, R. J. \&Palys, T.S. (Eds.) (1987) Transcarceration: Essays in the Sociology of Social Control. Aldershot: Gower.

Lucas, T. \&Williams, N. (2000) 'Motivation as a Function of Volunteer Retention'. Australian Journal on Volunteering, 5(1): 13-21.

Maguire, M. (2012) `Response 1: Big Society, the voluntary sector and the marketisation of criminal justice'. Criminology and Criminal Justice, 12(5): 483-505.

Martin, J. (2011) ‘Volunteer police and the production of social order in a Taiwanese village'. Taiwan in Comparative Perspective 3: 33-49.

Martin, B. \&Varney, W. (2003) ‘Nonviolence and Communication'. Journal of Peace Research, 40(2): 213-232.

Maurutto, P. \&Hannah-Moffat, K. (2016) Women's voluntary organisations and the Canadian penal 'culture of control'. In Hucklesby, A \& Corcoran, M. (Eds). The Voluntary Sector and Criminal Justice. London: Palgrave, pp. 171-188.

Mawby, R. I. (2016) 'Victim support in England and Wales: the end of an era?' International Review of Victimology, 22(3): 203-221.

Menzies, R. J. (1987) ‘Cycles of control: The transcarceral careers of forensic patients'. Intemational Joumal of Law and Psychiatry, 10(3): 233-249.

Middleton, J. \&Yarwood, R. (2015) ‘Christians, out here? Encountering Street-Pastors in the post-secular spaces of the UK's night-time economy'. Urban Studies, 52(3): 501-516. 
Millie, A. (2018) ‘Citizens in policing: the lived reality of being a Police Support Volunteer'. Policing and Society onlinefirst.

MoJ (2012). MAPPA Guidance 2012. Available online:

https://www.gov.uk/government/publications/multi-agency-public-protectionarrangements-mappa--2 (accessed 16 July 2018)

Mullen, J. (2018) What the future probation reforms mean for charities. Available online: https://www.civilsociety.co.uk/voices/jessica-mullen-what-the-future-probationreforms-mean-for-charities.html (accessed 06 August 2018)

Newburn, T. \& Shiner, M. (2006) 'Young people, mentoring and social inclusion'. Youth Justice, 6(1): 23-41.

O'Connor, T. P., Duncan, J., \& Quillard, F. (2006) ‘Criminology and religion: The shape of an authentic dialogue'. Criminology \& Public Policy, 5(3), 559-570.

Pepper, M. \& Silvestri, M. (2016) '"It's Like another Family Innit": Building Police-Youth Relations through the Metropolitan Police Service Volunteer Police Cadet Programme'. Policing, 11(1): 1-13.

Peterson, S. B. (2009) 'Made in America: The global youth justice movement'. Reclaiming Children and Youth, 18(2): 48-52.

Pierpoint, H. (2006) `Reconstructing the role of the appropriate adult in England and Wales'. Criminology and Criminal Justice, 6(2): 219-237.

Pierpoint, H. (2011). 'Extending and professionalising the role of the appropriate adult'. Journal of Social Welfare and Family Law 33(2): 139-155. 
Pitts, J. (2001) ‘Korrectional karaoke: New Labour and the zombification of youth justice'. Youth Justice, 1(2): 3-16.

Prison Reform Trust (2013). What Can I Do? Available at:

http://www.prisonreformtrust.org.uk/GetInvolved/WhatcanIdo (accessed 16 July 2018)

Prison Reform Trust (2017). Prison: the facts. Bromley Briefings Summer 201. Available at: http://www.prisonreformtrust.org.uk/Portals/0/Documents/Bromley $\% 20$ Briefings/Su mmer\%202017\%20factfile.pdf (accessed 16 July 2018)

Raine, J. W. \& Willson, M. J. (1995) `New public management and criminal justice’. Public Money and Management, 15(1): 35-40.

Ransley, J. \& Mazerolle, L. (2017) Third Sector Involvement in Criminal Justice. In Deckert, A. \& Sarre, R. (Eds.) The Palgrave Handbook of Australian and New Zealand Criminology, Crime and Justice. London: Palgrave Macmillan, pp. 483-496.

Rice, L. (2016) ‘The Wrong Side of the Frontline: Exploring the Utilisation of Civilian Investigators by Police Forces across England and Wales'. (unpublished PhD thesis, University of Sheffield, UK).

Richards, T. N., Tomsich, E., Gover, A. R., \& Jennings, W. G. (2016) ‘The cycle of violence revisited: Distinguishing intimate partner violence offenders only, victims only, and victim-offenders'. Violence and victims, 31(4): 573.

Robinson, G., Burke, L., \& Millings, M. (2015) ‘Criminal justice identities in transition: The case of devolved probation services in England and Wales'. British Journal of Criminology, 56(1): 161-178. 
Rochester, C. (2013). Rediscovering voluntary action: The beat of a different drum. London: Palgrave.

Roffee, J. A. (2017) 'Accountability and Oversight of State Functions: Use of Volunteers to Monitor Equality and Diversity in Prisons in England and Wales'. SAGE Open onlinefirst.

Rogan, M. (2009) `Visiting Committees and accountability in the Irish prison system: Some proposals for reform'. Dublin University Law Journal, 31: 298-323.

Rosenblatt, F. F. (2014) ‘Community involvement in restorative justice: lessons from an English and Welsh case study on youth offender panels'. Restorative Justice 2(3): 280301.

Sabri, A. Z. S. A., Mangsor, F., Majid, A. A., \& Rashidi, N. S. H. M. (2016) `Neighbourhood watch in Malaysia: Profiling Youth Leaders'. International Journal of Research in Economics and Social Sciences, 6(5): 199-208.

Salamon, L. M. (2015). 'Introduction: The nonprofitization of the welfare state'. Voluntas 26(6): 2147-2154.

Salole, A. T. (2016) Penal assemblages: Governing youth in the penal voluntary sector. In Abrams, L. S., Hughes, E., Inderbitzin, M., \& Meek, R. (Eds.) (2016) The Voluntary Sector in Prisons: Encouraging Personal and Institutional Change. New York: Springer, pp. $245-274$. 
Sharkey, P., Torrats-Espinosa, G., \& Takyar, D. (2017) ‘Community and the crime decline: the causal effect of local nonprofits on violent crime'. American Sociological Review, 82(6): 1214-1240.

Soldwedel, A. F. (2008) 'Testing Japan's Convictions: The Lay Judge System and the Rights of Criminal Defendants'. Vanderbilt Journal of Transnational Law, 41(5): 1417-1474.

South, J., Bagnall, A. M., \& Woodall, J. (2017) `Developing a typology for peer education and peer support delivered by prisoners'. Journal of Correctional Health Care, 23(2): 214-229.

Steinerte, E. \& Murray, R. (2009) ‘Same but Different? National human rights commissions and ombudsman institutions as national preventive mechanisms under the Optional Protocol to the UN Convention against Torture'. Essex Human Rights Review 6(2): 5472.

Stern, V. (2010) ‘The role of citizens and non-profit advocacy organizations in providing oversight'. Pace Law Review, 30(5): 1529-1534.

Suknaic, S. J. (1984) ‘Crime Victims-The Long-Ignored Cinderella’. PAPPC Journal 3(1): 3049.

Suzuki, Y. E. (2016) 'Public education of criminal justice in Japan: Increasing knowledge and challenging cultural values'. Japan Studies Association Journal 12: 57-65.

Svensson, K. (2009) 'Identity work through support and control'. Ethics and Social Welfare 3(3): 234-248. 
Thoits, P.A. \& Hewitt, L. N. (2001) 'Volunteer work and well-being'. Journal of Health and Social Behavior 42(2): 115-131.

Thomas, T. (2008) 'The sex offender 'register': A case study in function creep'. The Howard Journal of Crime and Justice, 47(3): 227-237.

Thompson, D. \&Thomas, T. (2017) The Resettlement of Sex Offenders After Custody: Circles of Support and Accountability. Abingdon: Routledge.

Tomczak, P. (2017) The Penal Voluntary Sector. Abingdon: Routledge.

Tomczak, P. and Buck, G. (2019) 'The penal voluntary sector: a hybrid sociology'. British Journal of Criminology OnlineFirst.

Tomczak, P. \&Thompson, D. (2017) 'Inclusionary control? Theorizing the effects of penal voluntary organizations' work'. Theoretical Criminology OnlineFirst.

van Eijk, C., Steen, T., \& Verschuere, B. (2017) 'Co-producing safety in the local community: A Q-methodology study on the incentives of Belgian and Dutch members of neighbourhood watch schemes'. Local Government Studies, 43(3): 323-343.

Wassenaar, M., Gradus, R., \& Molleman, T. (2017) Public vs. Nonprofit Incarceration: The Case of the Netherlands. Amsterdam: Tinbergen Institute Discussion Paper.

Welsh, L. (2016) ‘Magistrates, managerialism and marginalisation: neoliberalism and access to justice'. (unpublished PhD thesis, University of Kent, UK).

White, A. (2015) 'The politics of police 'privatization': A multiple streams approach'. Criminology and Criminal Justice, 15(3): 283-299. 
White, R., \& Kramer, R. C. (2015) ‘Critical criminology and the struggle against climate change ecocide'. Critical Criminology, 23(4): 383-399.

Whitehead, P. (2015) Reconceptualising the Moral Economy of Criminal Justice: A New Perspective. London: Palgrave.

Williams, K. S. (2016) Victims and the Voluntary Sector: A Torrid Affair. In Hucklesby, A. \&Corcoran, M. (Eds.) The Voluntary Sector and Criminal Justice. London: Palgrave, pp. 211-240.

Woodall, J. \&Kinsella, K. (2018) 'Striving for a "good" family visit: the facilitative role of a prison visitors' centre'. Journal of Criminal Psychology 8(1): 33-43.

Wooff, A. (2018) ‘Review: Kendall (2018) Regulating Police Detention’. Policing OnlineFirst. Young, P. (1992) 'The importance of utopias in criminological thinking'. British Journal of Criminology 32(4): 423-437.

Zedner, L. (2004) Criminal Justice. Oxford: Oxford University Press.

\footnotetext{
i Volunteering is the optional giving of time to perform tasks with no direct financial compensation (Thoits and Hewitt, 2001)

ii Voluntary organisations are heterogeneous, but are often registered charities. Differences include: functions; participants; income ranges; funding sources; size; aims; volunteer/ paid staff/ ex-offender proportions; relationship(s) with statutory agencies; faith/ secular basis (Tomczak, 2017; Kaufman, 2018)

iii E.g. social enterprises under payment by results contracts.

iv Lack of voluntary sector funding research was highlighted at the 2017 European Union hearing: Financing of civil society organisations.

v Voluntary organisations are given various, broadly synonymous names e.g. non-profit; third sector (Rochester, 2013).
} 
https://assets.publishing.service.gov.uk/government/uploads/system/uploads/attachment data/file/73 2765/Civil Society Strategy - building a future that works for everyone.pdf

vii https://victimsupport.eu/about-us/our-work/

viii Transcarceration illustrates diffusing regulatory institutions, practices, authorities and subjects across and beyond traditional state boundaries. Transcarceration demonstrates fluidity between 'outside' and 'inside' prison, illustrating post-release reconfinement (Allspach, 2010) and arrest, imprisonment and psychiatric detention cycles (Menzies, 1987). Broad applications could include policing, court, schools and families amongst regulators (Foucault, 1977; Lowman et al., 1987).

Nevertheless, the 'carceral' label again problematically foregrounds the prison and victims: "the true gatekeepers" of criminal justice: (Zedner, 2004: 15) are not naturally included, although it is recognised e.g. that women can be victim-offenders in domestic violence (Richards et al, 2016) and become trapped in transcarceral spaces as agents whose resistance has been criminalised (Allspach, 2010).

ix Although useful, Gill and Mawby (1990) predates for-profit privatisation and excludes court and prisons; Hucklesby and Corcoran (2016) do not consider policing, court or varying volunteer proportions within and outside voluntary organisations.

× https://s3-eu-west-2.amazonaws.com/npm-prod-storage-

19n0nag2nk8xk/uploads/2018/02/6.4122 NPM AR2016-17 v4 web.pdf

xi State-organised volunteer police are also found in e.g. the USA, which has an estimated 200,000 policing volunteers (Greenberg, 2014), Australia (Lucas and Williams, 2000) and Taiwan (Martin, 2011).

xii

http://apps.charitycommission.gov.uk/Showcharity/RegisterOfCharities/DocumentList.aspx?Register edCharityNumber=216066andSubsidiaryNumber=0andDocType=AccountList

xiii US correctional chaplains also often organise volunteers, including volunteer chaplains for minority religions. The Oregon Department of Corrections' chaplaincy team recruited and supervised over 1,400 volunteers from diverse faith groups in 2005, donating the equivalent of 121 full-time staff positions (O'Connor et al, 2006).

xiv S. 7(1) of the Prisons Act 1952.

${ }^{x v}$ Lord Bishops have a right of entry to prisons in their diocese and a voice in Parliament http://eprints.1se.ac.uk/76474/1/The\%20statutory\%20presence\%20of\%20the\%20Church\%20of\%20Engl and $\% 20 \mathrm{in} \% 20$ prisons $\% 20$ should $\% 20$ give $\% 20$ it $\% 20 \mathrm{a} \% 20$ voice $\% 20$ on $\% 20$ issues $\% 20$ of $\% 20$ imprisonmen t\%2C\%20but $\% 20$ it $\% 20$ remains $\% 20$ largely $\% 20$ silent $\% 20 \% 20$ Religion $\% 20$ and $\% 20$ the $\% 20$ Public $\% 20$ Sp here.pdf

xvi http://www.cgmcrc.co.uk/working-with-us/volunteering/.

xvii https://www.swmcrc.co.uk/careers-and-volunteering/volunteering/.

xviii Japan relies on volunteer probation officers (Suzuki, 2016). The Swedish Probation Service has for decades used volunteer probation officers: "to support, guide and encourage the client's efforts to not relapse into crime or drug abuse" (Franséhn, 2016: 103)._US Volunteer Probation Officers assist with a wide range of tasks in e.g. Sacramento County, the District of Connecticut, Eastern District of 
Michigan and Orange County Californiaxiii but have received scant attention. http://www.ocgov.com/gov/probation/employment/volunteer/vpo

xix https://www.magistrates-association.org.uk/about-magistrates/youth-court

xx https://www.gov.uk/government/uploads/system/uploads/attachment data/file/322209/fact-sheetyouth-referral-orders.pdf

xxi

https://www.derbyshire.gov.uk/social health/children and families/youth offending service/default .asp.

xxii https://s3-eu-west-2.amazonaws.com/layobservers-prod-storage-

nu2yj19yczbd/uploads/2017/10/Final-Lay-Observers-Annual-report-2016-7-.pdf

xxiii https://www.inquest.org.uk/inquest-jury-concludes-that-failures-by-the-police-serco-and-forensicmedical-examiner-contributed-to-the-death-of-sivaraj-tharmalingam..

xxiv https://s3-eu-west-2.amazonaws.com/imb-prod-storage-

1ocod6bqky0vo/uploads/2016/01/National-Monitoring-Framework.pdf

xxv https://www.gov.uk/government/news/appointment-of-dame-anne-owers-as-the-new-imbsnational-chair.

xxvi Most countries with a British colonial past have local lay prison oversight (Stern, 2010). Volunteer Visiting Committees inspect Irish prisons and hear prisoner complaints (Rogan, 2009). Western Australia's Independent Visitor Scheme enables officers and prisoners to discuss prison conditions with an impartial volunteer, who reports feedback to the Inspectorate (English, 2013).

xxvii http://amimb.org.uk/

https://www.theguardian.com/society/2016/nov/30/warned-prisoners-could-riot-minister-didnt-listen xxviii S. 326 Criminal Justice Act 2003.

xxix https://www.gov.uk/government/get-involved/take-part/help-make-your-neighbourhood-a-saferplace. Neighbourhood Watch is also found in e.g. the US, Netherlands, Australia, Belgium and Malaysia (Fleming, 2005; Sabri et al, 2016; van Eijk et al, 2017).

xxx http://apps.charitycommission.gov.uk/Accounts/Ends70/0001162670 AC 20161231 E C.pdf xxi http://apps.charitycommission.gov.uk/Accounts/Ends70/0001162670 AC 20161231 E C.pdf

xxxii Although surprisingly rarely studied, Crime Stoppers are found in about twenty countries, including the UK, US, Netherlands, Australia, India, and South Africa (Lippert and Wilkinson, 2010; Lippert and Walby, 2017). Canadian research has raised concerns that Crime Stoppers and police foundations have obfuscated "the flow of private funds into public police operations", in ways which may "shape public police priorities" (Lippert and Walby, 2017: 616).

xxxiii http://apps.charitycommission.gov.uk/Accounts/Ends87/0001108687 AC 20170331 E C.pdf

xxxiv http://apps.charitycommission.gov.uk/Accounts/Ends87/0001108687 AC 20170331 E C.pdf 
xxxv https://www.citizensadvice.org.uk/about-us/citizens-advice-witness-service/

xxxvi

https://www.citizensadvice.org.uk/Global/CitizensAdvice/citizens\%20advice\%20annual\%20report.pd $\mathrm{f}$

xxxvii Svensson (2009) notes, in Sweden, that victim support volunteers can act as an alibi for criminal justice, by gently persuading victims to bear witness at court.

xxxviii http://apps.charitycommission.gov.uk/Accounts/Ends28/0000298028 AC 20170331 E C.pdf

xxxix http://www.imb.org.uk/app/uploads/2015/01/send-2011.pdf

${ }^{x l}$ https://www.justiceinspectorates.gov.uk/hmiprisons/wp-content/uploads/sites/4/2014/06/Send-2014web.pdf

xli Volunteers work alongside paid staff at national victim support organisations in jurisdictions including: Austria, Netherlands, Denmark, Finland, France, Croatia, Czech Republic, Germany, Hungary, Portugal and Sweden (Jägervi and Svensson, 2015).

xlii http://apps.charitycommission.gov.uk/Accounts/Ends28/0000298028 AC 20170331 E C.pdf

xliii http://apps.charitycommission.gov.uk/Accounts/Ends28/0000298028 AC 20170331 E C.pdf

xliv http://apps.charitycommission.gov.uk/Accounts/Ends28/0000298028 AC 20170331 E C.pdf

xlv http://apps.charitycommission.gov.uk/Accounts/Ends28/0000298028 AC 20170331 E C.pdf

xlvi http://www.appropriateadult.org.uk/index.php/about-us/naan-map.

xlvii http://apps.charitycommission.gov.uk/Accounts/Ends65/0001104765 AC 20170331 E C.pdf

xlviii http://apps.charitycommission.gov.uk/Accounts/Ends32/0001091232 AC 20170331 E C.pdf

xlix http://www.remediuk.org/what-we-do-schools/

${ }^{1}$ https://www.catch-22.org.uk/services/realising-ambition/projects/safer-schools-partnership/

${ }^{\text {li http://outtheresfop.co.uk/. }}$

lii http://apps.charitycommission.gov.uk/Accounts/Ends42/0001120342 AC 20170331 E C.pdf 